\title{
SOCIOLOGY
}

\section{INSTITUTE SUPERVISION AS AN EFFECTIVE TOOL OF INSTITUTIONALIZATION IN THE SOCIAL SERVICES OF KAZAKHSTAN}

\author{
${ }^{1}$ Doctoral Student, Lyaziza G. Adilova, \\ ${ }^{2}$ PhD, Professor, Gulnara A. Abitova \\ ${ }^{1}$ Kazakhstan, Astana, Academy of Public Administration Under the President of the Republic of \\ Kazakhstan \\ ${ }^{2}$ Kazakhstan, Aktobe, Kazakh-Russian International University
}

DOI: https://doi.org/10.31435/rsglobal_ijitss/31012019/6327

\section{ARTICLE INFO}

Received 08 November 2018 Accepted 23 January 2019 Published 31 January 2019

\section{KEYWORDS}

social services, institute of supervision, effective tool, institutionalization. \begin{abstract}
The paper presents issues on institutionalization of the social services sphere in Kazakhstan in the framework of social modernization. In particular, it is the issue of increasing professionalism of social workers and supervisory support of specialists who works in special social services. Sociological surveys were conducted using a questionnaire surveys, interviews of experts, social workers. The institutional approach to increasing professionalism and competence of social workers, as well as an effectiveness of social work, was investigated on the basis of public opinion analyses. Based on the results of the empirical and sociological-statistical studies, the most critical factors of social service work have been identified and substantiated. Kazakhstan model of professional support to the provision of special social services is seen in the design of a new institutional model as Cross-Functional Institute of Supervision. This study contributes to optimization of the social work system and effectiveness of social services in future.
\end{abstract}

Citation: Lyaziza G. Adilova, Gulnara A. Abitova. (2019) Institute Supervision as an Effective Tool of Institutionalization in the Social Services of Kazakhstan. International Journal of Innovative Technologies in Social Science. 1(13). doi: 10.31435/rsglobal_ijitss/31012019/6327

Copyright: (C) 2019 Lyaziza G. Adilova, Gulnara A. Abitova. This is an open-access article distributed under the terms of the Creative Commons Attribution License (CC BY). The use, distribution or reproduction in other forums is permitted, provided the original author(s) or licensor are credited and that the original publication in this journal is cited, in accordance with accepted academic practice. No use, distribution or reproduction is permitted which does not comply with these terms.

Introduction. The goal of the study is to identify the main mechanisms for the establishment of supervision as an institutional factor for improving the quality of special social services. To achieve a goal, a following research tasks have been identified in the framework of this part of the study:

$\checkmark$ analyzing of possibilities of the establishment of supervision as an institutional mechanism of social work in Kazakhstan;

$\checkmark$ highlighting features of social work in different social systems;

$\checkmark$ collecting and analyze sociological information on the provision of special social services to people in difficult life situations.

The Evaluation of Scientific Study of the Problem and the Gaps in the Research Literature. At the present time in the scientific literature a significant amount is represented by developments around the evolution of social systems, the transformation of theoretical and practical approaches to the management of social development, the formation of social work as a sphere of professional activity, as well as its formalization into an independent educational category. The studies presented in the review of foreign literature show that International Western practice is characterized by a steady improvement and a constant study for social technologies in the sphere of social services. The 
scientific results of Kazakhstan scientists mainly concern the reform of social policy, state regulation of social services, raising the level of financial social assistance, training social workers, as well as the modernization of the social sphere in the country as a whole [1-5].

However, specifics of the institutionalization of the special social services system, as well as the increase of professionalism of social workers, have not yet been studied as a whole in Kazakhstan research. There are separate works on issues of supervision in medicine and health care. This fact determines a significance and novelty of subjects of research and realizes the object of research to improve the social sphere. It is expected the studies of the problem of professional support to social workers and a study of innovative mechanisms to ensure a quality of the provision of social services will closed the gaps in the research literature.

Currently, supervision in developed social systems is a common way of correction and professional development of specialists in the field of social work. In the international practice, supervision is also seen as an innovative form of organizing social work and coordinating the psychological, pedagogical, professional development of social workers [9-12]. In the Post-Soviet space, supervision is a new little-researched phenomenon and the main practice of its application has long been associated with the organization and implementation of activities of foreign companies that widely practice the policy of supporting their specialists through the help of mentors [13-15].

At present, in the economically developed countries of the world, supervision has an institutional status and is a significant resource providing personal support, increasing the professional qualification of employees and supporting them throughout their professional activities. In connection with these processes, the role and importance of the social worker of his rights and responsibilities has grown in the framework of the evaluation and definition of the need for special social services, a qualitative assessment and the definition of the need for special social services to the person (family) in a difficult life situation [16-18].

In this regard, the question of institutional approach to improving the professionalism and competence of social workers, as well as the effectiveness of social work, has been studied on the basis of the public opinion study. There are many factors that significantly affect to positive dynamics of social services work and to increase the competences of the professional group in the social structure of society. Development of advisory support to social workers, increasing of the role and status of social workers in public policy, improvement of a special social services quality is one of them. In the paper it was proposed methodological tools of sociological studies, such as surveys and interviews experts and specialists, social workers, social service agencies, categories of persons in a difficult situation, as well as statistical comparative analysis of the results of sociological research. Based on this tool, monitoring sociological surveys, as well as analysis and processing of research results were conducted.

Results and discussion. In the work, the list of status indicators was developed to identify a professional group of social workers and a group of people receiving special social services. These include: qualification, level of education, status and prestige of the profession, evaluation of the importance of social and labor values, the conditions for the success of working life, motives for choosing a profession, the relevance of the profession to education; level of satisfaction with work, working conditions, quality of service delivery; the degree of psych emotional state, risk factors, the level of professional qualities of specialists in the social sphere.

On these parameters, a sociological survey was conducted for the social and labor assessment of the professional activity of social workers and the quality of special social services. Sociological research was conducted in 2 stages: in 2015 and 2017. For these studies, special groups from people receiving special social services, as well as the categories of social workers dealing with problems of people who had fallen into a difficult life situation were selected.

At the first stage, surveys of social workers from 8 regional social service centers (from 16 regions of the republic) were conducted. There were respondents from such organizations as: Day Care Center, Department of Rehabilitation of Children and Adolescents, Home Health Care Center, Department of urgent service, Department of Social Services at Home. The first stage is devoted to conducting a sociological and statistical analysis of the professional qualities of social workers. Here, assessment of the level of professionalism and competence of specialists in social work in Kazakhstan is given, as well as factors influencing on them.

Using a comparative analysis in 2015 the sociological survey was carried out in social service institutions of the cities Almaty and Astana, in 2017 - in regional and city services (53 people). At the second stage of the sociological and statistical analysis, the sample size was increased to 55 social workers. At the second stage of the study, a survey and assessment of the risk factors affecting the productivity of social workers and quality of providing by them social services were conducted. In a 
selective set, there were already 150 social workers (from city and regions), which accounted for $73.5 \%$ of the total number of established posts for social workers.

In the study of the impact of working conditions on the psych emotional state and productivity of the work of specialists, the following facts were established. Social workers of social service centers and provision of special social services experience during the day, to a greater extent, the impact of negative "psychological" factors than "physical" factors, which is due to the specifics and nature of work. More than 50\% of the working time social workers at home are under the influence of "psychological" factors, rather than physical or material (Fig. 1). Comparative analysis for 2 years shows that the most significant among are the psychological instability of clients in the emotional sense, their depressiveness is $15.7 \%$ and $16.5 \%$, difficulties in communication and communication due to the lack or lack of pedagogicalpsychological experience or insufficiency work experience $-9,1 \%$ and $10,2 \%$.

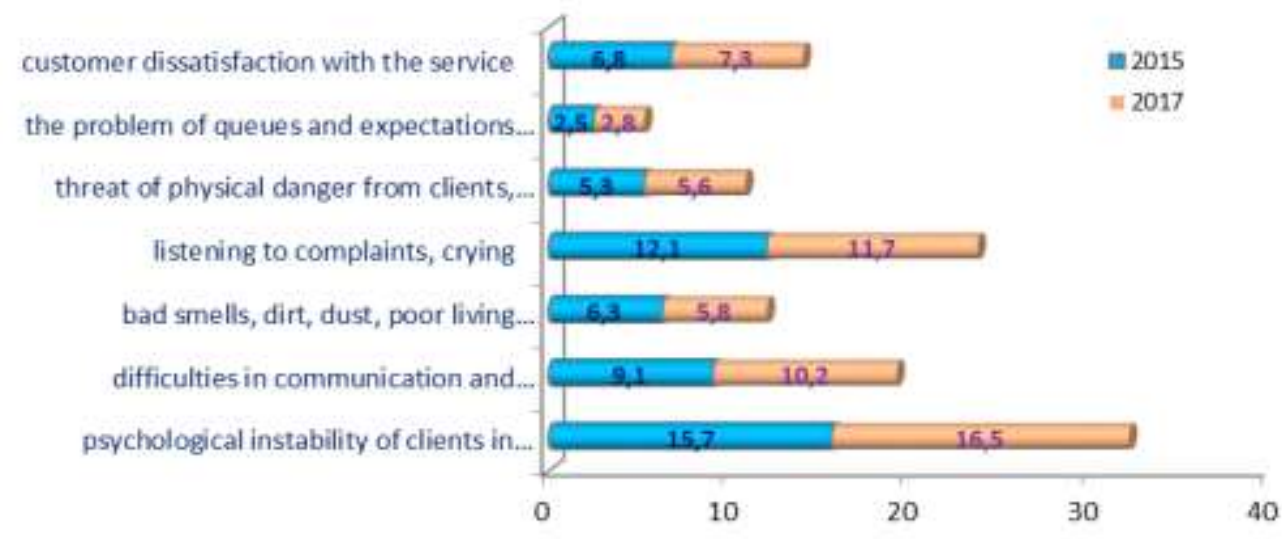

Fig.1. Diagram of comparative analysis of the impact of psychological Factors on the working conditions of social workers.

Source: made by the author according to sociological survey results.

One of the most important characteristics that affect to the productivity of social worker is a positive attitude toward his life, an optimistic mood. According to results of the analysis, it is obvious that this factor takes place, but the positivity of social workers is low. This is due in large part to the specificity of the category of people receiving social services and their negative impact on professionals.

Information on the types of activity and risk factors obtained as a result of the sociological and statistical analysis was confirmed and supplemented by the results of the questionnaire. The majority of social workers $(41.2 \%)$ have a feeling of extreme fatigue by the end of the working day. Practically zero indicator by the criterion "I do not feel fatigue at the end of the working day" $(0.2 \%)$. The overwhelming majority of social workers $(70.7 \%)$ believe that their working conditions adversely affect their health; $22.1 \%$ of respondents state that working conditions do not affect health; $9 \%$ - have a beneficial effect on health. In the answer to this question social workers of different departments were unanimous. $23.7 \%$ of respondents often experience a feeling of excessive physical stress, $20.5 \%$ - often in a state of psych emotional stress; $14.2 \%$ are in a state of great depression. Moreover, last two indicators have increased compared to 2015 (Fig.2).
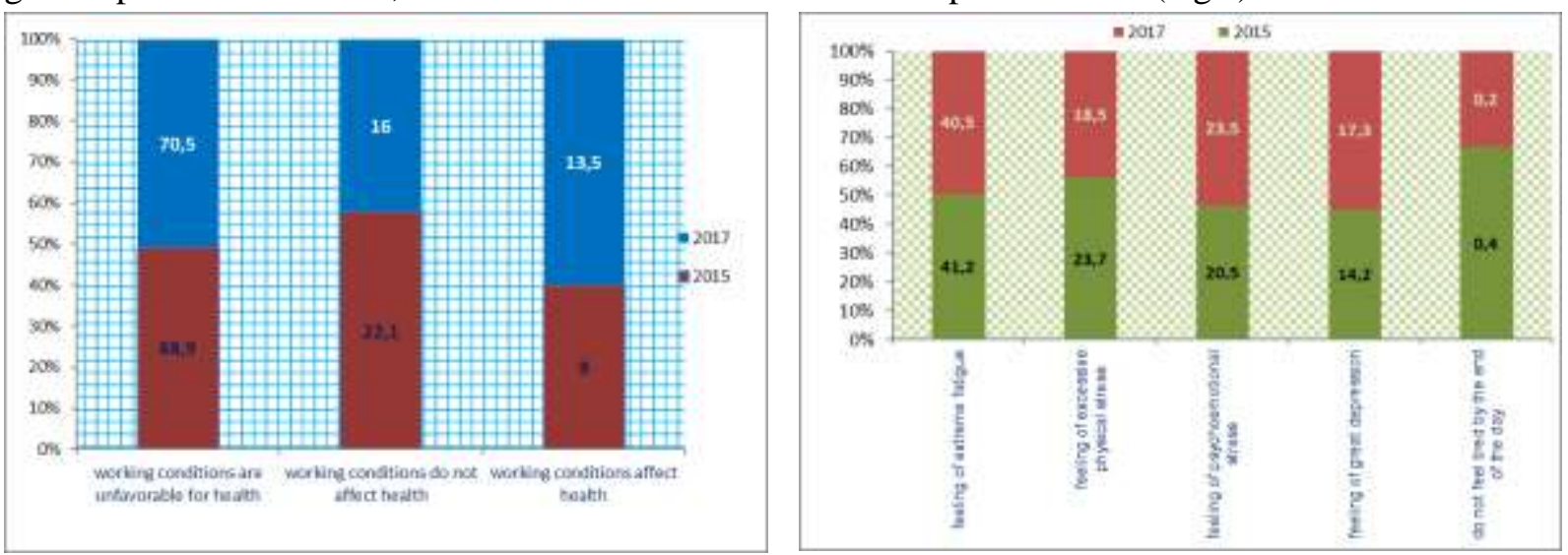

Fig.2 Comparative analysis of working conditions for the health of social workers. Source: made by Author according to sociological survey results. 
To determine the general set of parameters obtained with respect to labor values, a histogram and a distribution polygon were constructed. For this, the normal distribution and the Poisson distribution were used. From the obtained graphic data, it can be concluded that discrepancies between empirical and theoretical frequencies are random.

The respondents consider a lack of tools (instruments) for raising the level of education, acquisition of necessary experience, consulting support and training opportunities to mentors (supervisors) as the main risk factor for professional social work. At the second stage, analysis and assessment of risk factors affecting the productivity of social workers were carried out. One of the main factors of respondents is the feeling of excessive fatigue and psycho-emotional stress. The feeling of dissatisfaction with the help given to clients comes from a lack of experience and knowledge in related fields. Experiments speak about the need for urgent intervention and the creation of tools for the rehabilitation and correction of the physical and psycho-emotional status of social care professionals.

Conclusions. Thus, as a result of conducted sociological research and statistical processing of empirical information (based on quantitative methods of data analysis), the following main conclusions were obtained. The nature and working conditions during the performance by the social workers of their basic functions can be assessed as unfavorable in terms of the possibilities of maintaining and promoting health (physical and psych emotional). It is necessary to carry out preventive measures to prevent risk factors and introduce corrective tools to increase the productivity of social workers. And, of course, it is necessary to introduce a new Social Institute as a Cross-Functional Institute for Supervision of Social Work. Within the framework of such an institutional approach, it is possible to develop programs for continuing professional development, where various trainings for the development of communication skills, service skills, and self-correction skills would be provided.

In this sociological study, the institutional approach to improving the professionalism and competence of social workers, as well as the effectiveness of social work, was explored on the basis of public opinion research. Based on the results of the empirical and sociological-statistical studies, the most critical factors were identified and justified. These factors influence both the development of professional qualities and the productivity of social workers in the service sector. The results of the analysis confirmed our assumptions about the influence of risk factors. The main factors are the development of advisory support for social workers by more experienced specialists, the enhancement of the role and prestige of the profession of social work, the improvement of the quality of the provision of special social services through social work institutions, etc. All these measures and mechanisms must significantly affect the positive dynamics of the work of social services and social workers, as well as to increase the competence of the professional group in the social structure of society. Therefore, in our opinion the design an institute supervision is an effective tool increasing for the social service quality and for developing a professional skill of the social workers and specialists. In the long term, the research will focus on the issues of solving the problems of competency-based training of personnel for this sphere, enhancing the prestige of social workers, and the formation of the cross-functional institute of supervision as an innovative institute for the social sphere.

\section{REFERENCES}

1. Taibova O. (2006) Gosudarstvennoe upravlenie v oblasti zashhity i zashhity nesovershennoletnih: administrativnyj i pravovoj aspekt. Thesis for the degree of candidate of legal sciences. St. Petersburg: North-West Academy of Public Administration. (In Russ.).

2. Murtazalieva M. (2005) Social'no-pedagogicheskaja profilaktika prestupnosti sredi nesovershennoletnih. Thesis for the degree of candidate of pedagogical sciences. Makhachkala: Dagestan. GPU. (In Russ.).

3. Hadzhimba L. (2007) Social'noe vzaimodejstvie organov gosudarstvennogo i municipal'nogo upravlenija v oblasti predotvrashhenija deviantnogo povedenija nesovershennoletnih. Thesis for a candidate of sociological sciences degree. Saratov: Saratov Law Institute of the Ministry of Internal Affairs of Russia. (In Russ.).

4. Nurumova G. (2014) Gosudarstvennaja social'no-integrirovannaja politika v otnoshenii netipichnyh detej. Thesis for the degree of Doctor Ph.D. Astana. (In Russ.).

5. Tezekbaeva Z. (2014) Social'naja politika i ee vlijanie na adaptaciju pozhilyh ljudej. Thesis for the degree of Doctor Ph.D. Astana. (In Russ.).

6. Dzhamanbalaeva Sh. (2002) Novye podhody k organizacii social'noj zashhity detej i podrostkov. Eurasian community: society, politics, culture. 2002. 1 (37): 59.

7. Kozhamkulova L. (2003) Professional'naja terapija v social'noj rabote: opyt SShA. Politics. 6 (96): 46-47. (In Russ.).

8. Nurkatova L. (2010) Cennostno-semanticheskie orientacii u lic s suicidal'nymi tendencijami. Thesis for the degree of Doctor Ph.D. Almaty: KazNU. (in Russ.).

9. Gaskin L. (2003) Supervision of participants. In D. Cotten \& J. Wolohan (Eds.) Law for recreation and sport managers. Dubuque, IA: Kendall/Hunt. (3rd Ed.): 138-148. 
10. Thompson D., Hudson S. \& Olsen H. (2007) S.A.F.E play areas: Creation, maintenance, and renovation. Champaign, IL: Human Kinetics.

11. PUIG CRUELLS C. (2014). Supervision of Child Social Care Teams: A Method to Ensure Quality Services. Revista de Cercetare Ssi Interventie Sociala, Vol.45, 200-214.

12. Barenblit V. (1997). Supervisión de equipos sanitarios en distintas instituciones. [V Jornadas Nacionales de APAG, Asociación de Psicoterapia Analítica. San Sebastián]. Available at: http://www.apagnet.net/publicaciones/textos/grup10.html (accessed 15 October 2018).

13. Belykh O. (2009) Osobennosti upravleniya social'noy reabilitaciej nesovershennoletnih s deviantnym povedeniem. Thesis for a candidate of sociological sciences degree M.: MGU. (In Russ.)

14. Brjanceva M. (2009) Social'naya politika gosudarstva v otnoshenii nesovershennoletnih v usloviyah transformacii social'noy sistemy Rossii. Thesis for a candidate of sociological sciences degree M.: NNGU. (In Russ.).

15. Chapurko T. (2008) Gosudarstvennyja politika sovremennoj Rossii v oblasti zashhity prav i interesov nesovershennoletnih. Thesis for the degree of candidate of humanities. Rostov-na-Donu: North Caucasus Academy of Public Administration. (In Russ.).

16. Cruells C. (2014) Supervision of Child Social Care Teams: A Method to Ensure Quality Services. Revista de Cercetare Ssi Interventie Sociala. 45(1): 200-214.

17. Van der Smissen (2007) B. Elements of negligence. In D. Cotten \& J. Wolohan (Eds.). Law for recreation and sport managers. Dubuque, IA: Kendall/Hunt. (4th Ed.): 36-45. 